\title{
Effect of leaf movement on epiphytic algal biomass of seagrass leaves
}

\author{
Paul S. Lavery*, Tara Reid, Glenn A. Hyndes, Beverley R. Van Elven \\ Centre for Ecosystem Management, Edith Cowan University, 100 Joondalup Drive, Joondalup, Western Australia 6027, Australia
}

\begin{abstract}
We tested the hypothesis that the movement of seagrass leaves affects the accumulation and composition of algal epiphytes by comparing the standing crop and composition on tethered (T) and untethered (UT) artificial seagrass units (ASUs) over 4 and $8 \mathrm{wk}$. We also tested whether any effect of leaf movement on standing crop was dependent on the degree of water movement by repeating the experiment over $8 \mathrm{wk}$ at sheltered and exposed sites. To eliminate the possibility of inter-regional differences between exposed and sheltered sites and to test for interactive effects of light availability and leaf movement on epiphyte biomass, we repeated the experiment at a single location, but at different depths, to achieve different hydrodynamic and light conditions. In the first experiment, T ASUs accumulated between 4 and 12 times the biomass of algal epiphytes on UT ASUs. Fewer species were found on UT leaves after $4 \mathrm{wk}$, but by $8 \mathrm{wk}$, there were similar numbers of species on both treatments. The degree of exposure did not influence the effect of leaf movement on epiphyte biomass, but depth did, with a significant but smaller difference between treatments at the deeper site. We conclude that leaf movement has a clear and significant potential to affect the accumulation of epiphytes on seagrass leaves and that this effect may be comparable to, if not more important than, nutrient and light limitation in some circumstances. The movement of seagrass leaves result in up to a 7 -fold increase in light penetration due to reduced epiphyte standing crop. If the effect of leaf movement on epiphyte biomass is through physical erosion, then estimates of the contribution of epiphytes to carbonate production and organic loading to sediments must factor in an erosion loss term.
\end{abstract}

KEY WORDS: Seagrass · Posidonia sinuosa $\cdot$ Epiphytes · Macroalgae $\cdot$ Leaf movement $\cdot$ Erosion Resale or republication not permitted without written consent of the publisher

\section{INTRODUCTION}

Epiphytic macroalgae can account for $>50 \%$ of the standing stock and primary productivity of seagrass meadows (Silberstein et al. 1986, Wear et al. 1999, Borowitzka et al. 2006). Many grazers show a preference for epiphytic algae over their seagrass hosts (Klumpp et al. 1992, Jernakoff et al. 1996). As a result, epiphytes can make significant contributions to the productivity of seagrass communities. In some seagrass ecosystems, epiphytic algae can be an important component of the habitat complexity provided by the canopy and calcifying algae can be a significant source of biogenic carbonate, contributing to sediments (Patriquin 1972, Walker \& Woelkerling 1988, Frankovich \& Zieman 1994). They can also be important in nutrient cycling, with cyanobacterial epiphytes contributing to N-fixation (Iizumi \& Yamamuro 2000, Pereg-Gerk et al. 2002) and other algae acting as nutrient 'sinks' (Cornelisen \& Thomas 2002). Conversely, epiphytic algae have been associated with large-scale losses of seagrasses in eutrophic waters (Silberstein et al. 1986, Walker \& McComb 1992).

Given the clear importance of macroalgal seagrass epiphytes, any understanding of the functions of seagrass ecosystems requires an understanding of the associated epiphytes and their functions. The standing crop of epiphytes on seagrasses is the result of the cumulative effects of interacting factors, including propagule recruitment, light and nutrient availability, temperature, herbivory and water movement. Most of these factors have been studied in some detail (see 
Borowitzka et al. 2006), but the role of water movement and its effect on the accumulation of seagrass epiphytes has largely been ignored. The structure, and the movement of seagrass leaves in response to water movement influences water velocity profiles through canopies (Verduin 1996), with consequences for boundary layer structure, which affects propagule recruitment (Charters et al. 1973) and dissolved nutrient uptake (e.g. Cornelisen \& Thomas 2002).

Physical damage is a clear result of leaf motion, and is hypothesised to remove epiphytes from seagrass leaves (Borowitzka et al. 2006). This presumption was supported in preliminary studies, where we observed large differences in the standing crop of epiphytes that were associated with the leaf movement. Studies addressing the role of epiphytic macroalgae in seagrass ecosystems often assume that the standing crop of epiphytic algae is equivalent to the gross epiphytic growth over the lifespan of the leaf (e.g. Hegge et al. 1998). However, if leaf movement does affect the standing crop, and if this occurs through erosion of epiphytes, then the total contribution of epiphytes to sediment production, for example, will be underestimated. Similarly, if leaf movement controls the standing crop of seagrass epiphytes, it may offset the negative consequences of eutrophication.

An emerging body of research is increasingly showing that the effects of key bottom-up controls on epiphyte biomass (light and nutrients) may not be simple. Heck et al. (2000) have shown that grazers can ameliorate the effects of nutrient additions. Similarly, Schanz et al. (2002) showed that complex hydrodynamics-grazer interactions can control epiphyte accumulation. These observations indicate that factors other than light and nutrients may play an important role in controlling epiphytic algae biomass, either alone or through interactions with other key controls. Based on our earlier observations, we hypothesised that leaf movement exerts a strong control on the standing crop of epiphytes and that this could be significant enough to warrant consideration in estimates of epiphyte and seagrass ecosystem function. The aim of this work was therefore to test the hypothesis that the movement of seagrass leaves can affect the accumulation of epiphytes. We also sought to test whether any effect of leaf movement was dependent on the degree of water movement at a site.

\section{MATERIALS AND METHODS}

Study area. This study was conducted off the eastern shoreline of Garden Island (GI; $32^{\circ} 15^{\prime} \mathrm{S}, 115^{\circ} 45^{\prime} \mathrm{E}$ ) and in the Marmion Marine Park (MMP) near Perth, Western Australia (Fig. 1). GI protects extensive sea-

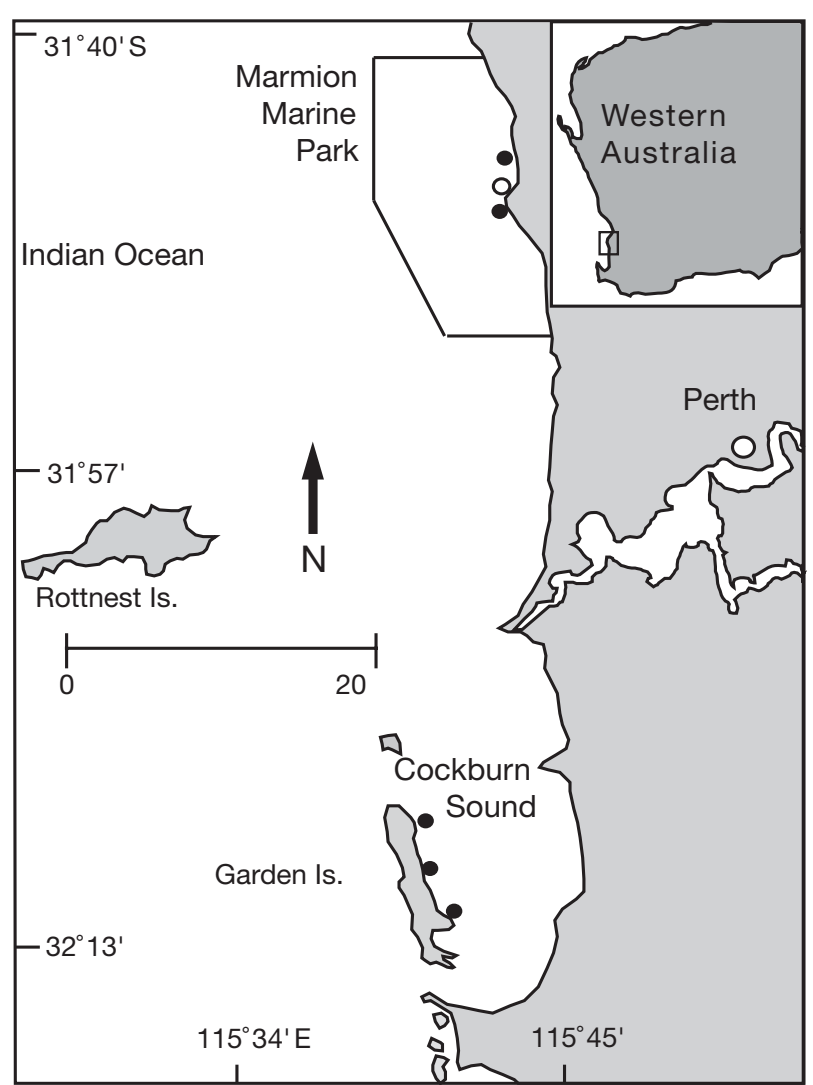

Fig. 1. Study sites. Open circle in Marmion Marine Park (MMP): site used for the 4 and 8 wk deployments of artificial seagrass. All sites were used in the exposed vs sheltered experiment $(\mathrm{MMP}=$ exposed, Cockburn Sound $=$ sheltered $)$. Sites in Cockburn Sound were stratified into shallow and deep areas (within $150 \mathrm{~m}$ of each other) for the depth experiment

grass meadows on its eastern shore from the predominant SW winds and swells of the region (Pattiaratchi et al. 1997). MMP is considerably more exposed. Both locations contain diverse assemblages with several species of seagrass, including Posidonia and both species of Amphibolis. The locations used in the study were dominated by extensive $P$. sinuosa meadows growing on medium-coarse calcareous sands.

Three experiments were conducted. The first tested for effects of leaf movement on the accumulation of macroalgal epiphyte biomass. The second and third tested for the potential confounding effects of exposure and water depth on leaf movement.

All 3 experiments used artificial seagrass leaves (ASLs) that were similar in structure to the strap-like leaves of Posidonia. ASLs have been shown to be useful in performing epiphyte colonisation studies, as they can be used to make identical replicate leaves removing confounding effects of variable leaf size and age (Lethbridge et al. 1988). Artificial seagrass units have been used in other studies and were shown to yield 
similar epiphytic communities and accumulation of biomass to those growing on natural seagrasses in this region (Horner 1987, but see Pinckney \& Micheli 1998 for other regions).

ASLs were constructed of clear plastic polyethylene strips $(1 \times 10 \times 250 \mathrm{~mm})$ that are not known to inhibit epiphytic algal recruitment (Horner 1987). Thirty plastic leaves were stapled to plastic-coated wire grids measuring $0.0625 \mathrm{~m}^{2}(0.25 \times 0.25 \mathrm{~m})$, at a density of 35 leaves $0.0625 \mathrm{~m}^{-2}$. To mimic natural seagrass leaves, untethered (UT) leaves were attached to the grids only at the bottom, allowing them free movement in response to local hydrodynamics, which in shallow wave-dominated conditions results in periodic reorienting of the leaves in the downstream direction. UT leaves were constructed by mounting the grid with its leaves into the base of a cuboid frame made of marine grade stainless steel. Tethered $(\mathrm{T})$ leaves were constructed by placing a second grid on the top of the frame and stapling the tops and bottoms of the plastic leaves to the top and bottom grids. This prevented any lateral movement of the plastic leaves and provided a mimic of a natural seagrass leaf, but with the potential of movement removed. A cuboid frame with its associated grid and leaves is hereafter referred to as an artificial seagrass unit (ASU).

Replicate ASUs ( $\mathrm{n}=5$ for each treatment) were deployed for either 4 or $8 \mathrm{wk}$, which is within the average life span of Posidonia leaves (60-120 di Cambridge \& Hocking 1997) and is sufficient time for algal epiphyte assemblages to accumulate on natural leaves. ASUs were placed randomly within sand patches surrounded by seagrass meadow. On retrieval, each ASU was placed in a plastic bag underwater to ensure minimal loss of epiphytic material during handling. On board, the grids were separated from the frames and stored in a cool, dark container for transport to the laboratory, where they were processed to determine epiphytic algal biomass and composition within $12 \mathrm{~h}$ of retrieval.

Effect of leaf movement on epiphytic standing stock and species composition. To test for the effect of leaf movement on the standing crop of epiphytes on seagrass leaves, we measured the accumulation of epiphytic algal biomass on $\mathrm{T}$ and UT seagrass leaves located in $3 \mathrm{~m}$ of water at 1 site in MMP. The difference in epiphytic biomass that accumulated on the 2 different forms of ASU over 2 time intervals was a quantification of the effect of leaf movement on epiphyte accumulation. Differences in the effect of leaf movement over time could then be related to post-recruitment processes.

Ignoring the outermost 'leaves', 10 leaves were randomly selected from each ASU and cut from the grid at the points of attachment for biomass analysis. A further
5 leaves were randomly selected for analysis of species composition. Pilot studies had shown this level of sampling to be optimum for sampling of epiphytic biomass and to provide an accurate representation of species richness. Dry weight (DW) and ash-free dry weight (AFDW) were determined to allow the proportion of calcified algae to be determined. The lowest $5 \mathrm{~cm}$ of the leaf was removed to exclude the area affected by staples and to standardise the surface area of each leaf. Epiphytic algae were then scraped from both sides of the leaves with a flat edged razor blade. Epiphyte DW and AFDW, from the bulked 10 leaves, was determined as per Kendrick \& Lavery (2001), and normalised to per-leaf basis.

Epiphytes present on the remaining harvested leaves, minus the bottom $5 \mathrm{~cm}$ stapled section, were identified to the lowest taxonomic level possible, using keys found in Womersley $(1984,1987,1994,1996)$ and Huisman \& Walker (1990). To determine percent coverage of each species on each leaf, a transparent $1 \times$ $1 \mathrm{~mm}$ grid was overlaid on the leaf, and the proportion of intercepts on which the species occurred was recorded.

Differences in epiphytic algal biomass and species richness between times and between tethering treatments were tested using a 2-factor orthogonal analysis of variance (ANOVA). All data were then tested for homogeneity of variances using Levene's test $(\mathrm{p}>$ 0.05). In all cases, variances were homogeneous. Where significant main effects were detected, post hoc comparisons (Tukey-Kramer) were performed.

The species composition of epiphytes on $\mathrm{T}$ and UT leaves at 4 and 8 wk were also compared using nonparametric multivariate analyses found in the PRIMER software package (Carr 1997). Bray Curtis similarity matrices were constructed from species percentage cover data, using each leaf as a sample $(\mathrm{n}=50 \mathrm{~T}$ and 50 UT). Ordinations (nonmetric multidimensional scaling, n-MDS) of the similarity matrix were used to visually inspect differences in the composition of epiphytes from different types of ASUs and times. Two-way crossed analysis of similarity (ANOSIM) was used to test for significant differences in species composition between treatments and times.

Influence of exposure. Any effect of leaf movement on epiphyte accumulation may be moderated by differences in exposure and resultant water movement among sites. To test for such effects, we repeated the previously described experiment at sheltered and exposed sites. Three replicate 'sheltered' sites were chosen along the eastern side of GI in Cockburn Sound, and 3 'exposed' sites were chosen in MMP (Fig. 1). At each site, replicate $(n=3) \mathrm{T}$ and UT ASUs were deployed at a depth of $3 \mathrm{~m}$ for $8 \mathrm{wk}$, after which the ASUs were removed and processed for algal bio- 
mass using the same procedures described above. The experimental design for this experiment corresponded to a 2-factor nested ANOVA with treatment and exposure considered as fixed factors. Site was nested within exposure level. Prior to ANOVA, all data were treated as described previously.

Differences in exposure between exposed and sheltered sites were quantified using 2 approaches. First, the velocity of water movement in 2 horizontal planes (X and Y), which reflects orbital wave velocities, was measured at the height of the seagrass canopy for 15 min using an Acoustic Doppler Velocimeter (ADV) Profiler (Nikora \& Goring 1998). Higher velocities and greater variation in water movement was interpreted as higher levels of exposure. In addition, the effective fetch (Håkansson 1981) was calculated for each site as a measure of wave exposure. The effective fetch value $\left(L_{\mathrm{f}}\right)$ was calculated as $L_{\mathrm{f}}=\left(\Sigma \chi_{\mathrm{i}} \cos \gamma_{\mathrm{i}}\right) /\left(\Sigma \cos \gamma_{\mathrm{i}}\right)$, where $\chi_{\mathrm{i}}$ is the distance in $\mathrm{km}$ to the nearest land, measured in 15 directions $(\gamma)$ with deviation angles $\left(\gamma_{i}\right) \pm 6,12,18$, $24,30,36$ and $42^{\circ}$ from a central radius (0). The central radius was placed in the direction giving the highest value of $L_{\mathrm{f}}$. Wikström et al. (2002) have previously categorised sites as sheltered $\left(L_{\mathrm{f}}<1\right)$, intermediately exposed $\left(L_{\mathrm{f}}=1-10\right)$ or highly exposed $\left(L_{\mathrm{f}}>10\right)$.

Influence of depth. To test for any interaction between leaf movement and light availability on the standing crop of epiphyte biomass, an additional experiment was conducted in which ASUs were placed in 'deep' (8 m) and 'shallow' (3 m) depths at 3 locations along the eastern side of GI, separated by $>3 \mathrm{~km}$. In this region, there is a steep gradient in bathymetry so that within each location, the $3 \mathrm{~m}$ and $8 \mathrm{~m}$ depths were $<150 \mathrm{~m}$ apart, thus minimising the potential for major differences in water quality and proximity to possible sources of epiphyte propagules, while creating large differences in light availability. This design also complemented the design of Expt 2, in which there was the possibility of inter-regional differences confounding any interactive effect of tethering and exposure on epiphyte biomass. For example, regional differences in recruitment pools may affect algal biomass. Since, for shallow water waves, the orbital velocity associated with waves is inversely proportional to depth (Open University Press Team [OUP] 1989), deep sites have lower water motion for a given wind wave condition at the surface, but potential inter-regional differences in water quality and propagule availability were minimised. At each site, replicate $\mathrm{T}$ and UT ( $\mathrm{n}=3$ each) ASUs were deployed for $8 \mathrm{wk}$, after which time they were retrieved and processed for biomass determinations as described earlier.

Differences in accumulation of epiphyte biomass due to tethering, depth or location nested within depth were tested using a 2-factor nested ANOVA, with fixed factors of treatment and depth, and the factor site nested within depth (see Table 1). The data failed Levene's test for homogeneity of variance and were subsequently square-root transformed, resulting in homogeneity ( $p>0.05)$.

\section{RESULTS}

\section{Effect of tethering on epiphytic biomass and composition}

There was a clear effect of tethering on epiphytic algal biomass of ASUs (Fig. 2) as shown by the treatment $\times$ time interaction $(p<0.001$; Table 1$)$. The interaction was due to increasing accumulation of epiphyte biomass over time on $\mathrm{T}$ leaves and very little accumu-
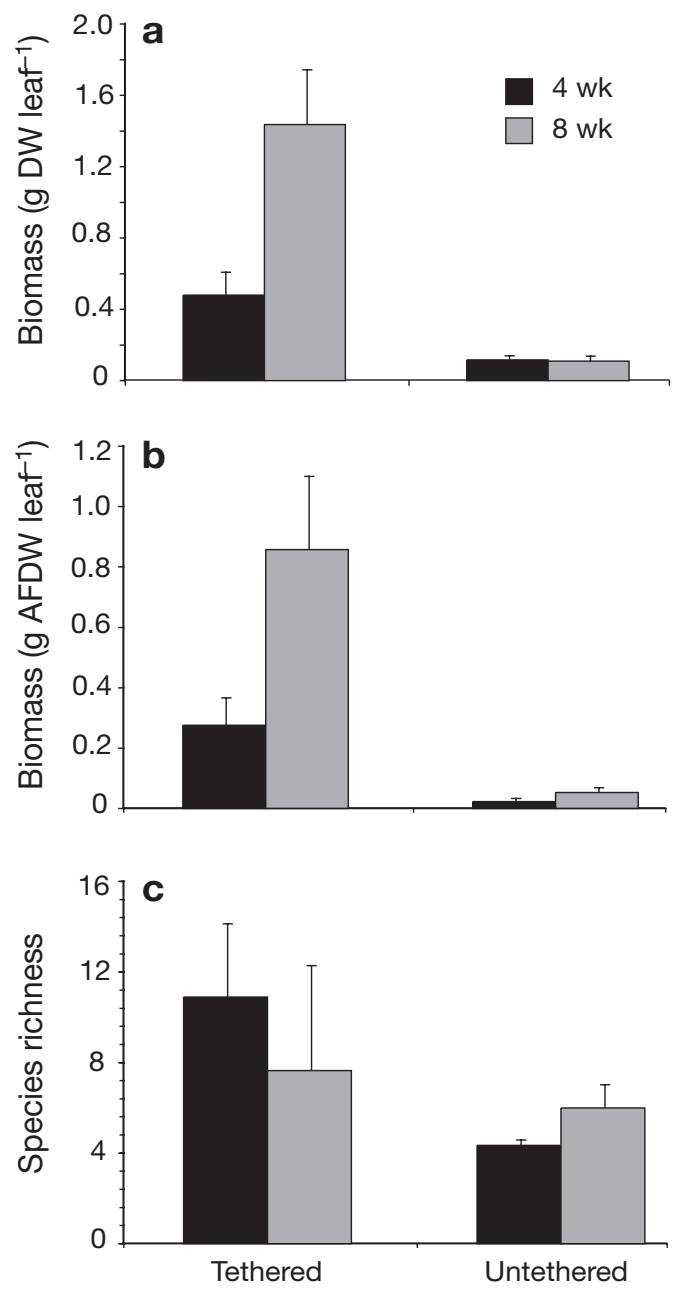

Fig. 2. Mean biomass expressed as (a) dry weight and (b) ashfree dry weight, and (c) species richness, recorded on tethered and untethered artificial seagrass leaves over 4 wk (dark bars) and 8 wk (light bars) in Marmion Marine Park, Western Australia. $\mathrm{n}=5$; error bars: $\pm \mathrm{SE}$ 
Table 1. ANOVA of: (1) 2-factor ANOVA testing differences in biomass and species richness of seagrass epiphytes between tethered (T) and untethered (UT) artificial seagrass units (ASUs) and time intervals (4 and $8 \mathrm{wk}$ ); (2) 2-factor nested ANOVA testing for differences in biomass of seagrass epiphytes between T and UT ASUs and exposure (sheltered and exposed sites); and (3) 2-factor nested ANOVA testing for differences in biomass of seagrass epiphytes between $T$ and UT ASUs and depth (shallow and deep sites). Dry weight and ash-free dry weight (AFDW) data were square-root transformed in the tethering and depth analysis. ${ }^{* *}=p<0.01$, ${ }^{* * *}=\mathrm{p}<0.001$; ns: not significant

\begin{tabular}{|c|c|c|c|c|}
\hline Variable and factor & df & MS & $F$ & $\mathrm{p}$ \\
\hline \multicolumn{5}{|c|}{ (1) Tethering (Te) and time (T) } \\
\hline \multicolumn{5}{|c|}{ Dry weight } \\
\hline $\mathrm{T}$ & 1 & 103.063 & 38.103 & $* * *$ \\
\hline $\mathrm{Te}$ & 1 & 306.808 & 113.430 & $* * *$ \\
\hline $\mathrm{T} \times \mathrm{Te}$ & 1 & 103.063 & 38.103 & $* * *$ \\
\hline \multicolumn{5}{|l|}{ AFDW } \\
\hline $\mathrm{T}$ & 1 & 112.063 & 67.716 & $* * *$ \\
\hline $\mathrm{Te}$ & 1 & 37.294 & 22.535 & $* * *$ \\
\hline $\mathrm{T} \times \mathrm{Te}$ & 1 & 37.294 & 22.535 & $* * *$ \\
\hline \multicolumn{5}{|l|}{ Species richness } \\
\hline $\mathrm{T}$ & 1 & 12.8 & 1.45 & ns \\
\hline $\mathrm{Te}$ & 1 & 36.2 & 39.015 & ** \\
\hline $\mathrm{T} \times \mathrm{Te}$ & 1 & 120.05 & 13.932 & ** \\
\hline \multicolumn{5}{|l|}{ (2) Te \& Exposure (E) } \\
\hline \multicolumn{5}{|l|}{ Dry weight } \\
\hline E & 1 & 1.289 & .505 & ns \\
\hline Site (E) & 4 & 4.328 & .424 & $\mathrm{~ns}$ \\
\hline $\mathrm{Te}$ & 1 & 222.844 & 87.328 & $* * *$ \\
\hline $\mathrm{E} \times \mathrm{Te}$ & 1 & 0.425 & 0.096 & ns \\
\hline \multicolumn{5}{|l|}{ AFDW } \\
\hline $\mathrm{E}$ & 1 & 3.178 & 2.460 & ns \\
\hline Site (E) & 4 & 2.105 & 0.390 & ns \\
\hline $\mathrm{Te}$ & 1 & 67.457 & 52.211 & $* * *$ \\
\hline $\mathrm{E} \times \mathrm{Te}$ & 1 & 2.121 & 1.643 & ns \\
\hline \multicolumn{5}{|l|}{ (3) Te \& Depth (D) } \\
\hline \multicolumn{5}{|l|}{ Dry weight } \\
\hline $\mathrm{D}$ & 1 & 47.804 & 63.508 & $* * *$ \\
\hline Site (D) & 4 & 0.402 & 0.534 & ns \\
\hline $\mathrm{Te}$ & 1 & 66.546 & 88.408 & $* * *$ \\
\hline $\mathrm{D} \times \mathrm{Te}$ & 1 & 31.734 & 48.317 & $* * *$ \\
\hline \multicolumn{5}{|l|}{ AFDW } \\
\hline $\mathrm{D}$ & 1 & 13.087 & 35.140 & $* * *$ \\
\hline Site (D) & 4 & 0.509 & 0.772 & ns \\
\hline $\mathrm{Te}$ & 1 & 21.065 & 56.564 & $* * *$ \\
\hline $\mathrm{D} \times \mathrm{Te}$ & 1 & 10.325 & 27.724 & $* * *$ \\
\hline
\end{tabular}

lation over time on UT leaves. DW and AFDW of algal epiphytes were substantially greater on $\mathrm{T}$ leaves than on UT leaves after 4 and 8 wk (Fig. 2). The ratio of AFDW to total DW on UT leaves ranged from 0.3 after $4 \mathrm{wk}$ to 0.6 after $8 \mathrm{wk}$, indicating a higher proportion of inorganic material in the $4 \mathrm{wk}$ samples. The ratio was consistently about 0.6 for $\mathrm{T}$ leaves.

A total of 53 species of algae were found on the ASUs (Table 2). With one exception, rhodophytes comprised $60-75 \%$ of the identified taxa; UT samples taken after
Table 2. Species of macroalgal epiphytes found on tethered (T) and untethered (UT) artificial seagrass leaves after 4 and 8 wk. Species are ordered to clarify the differences among treatments and times. $\mathrm{C}=$ Chlorophyta, $\mathrm{P}=$ Phaeophyta and $\mathrm{R}=$ Rhodophyta $; \mathrm{cf}=$ corticated filament, cfo $=$ corticated foliose, $\mathrm{e}=$ encrusting, $\mathrm{f}=$ filamentous, fo $=$ foliose, $\mathrm{s}=$ saccate. Different but unidentified species within a taxon are indicated by, for example, Chlorophyta sp 1, 2

\begin{tabular}{|c|c|c|c|c|c|}
\hline \multirow{2}{*}{ Species } & \multirow{2}{*}{ Type } & \multicolumn{2}{|c|}{ After 4 wk } & \multicolumn{2}{|c|}{ After 8 wk } \\
\hline & & $\mathrm{T}$ & UT & $\mathrm{T}$ & UT \\
\hline Antithamnion armatum & $\mathrm{Rf}$ & + & & + & \\
\hline Antithamnion hanowiodes & $\mathrm{Rf}$ & + & & & \\
\hline Audouinella daviesii & $\mathrm{Rf}$ & + & & & \\
\hline Bryopsis foliosa & $\mathrm{Cf}$ & + & & & \\
\hline Cholorophyta sp 2 & $\mathrm{Cf}$ & + & & & \\
\hline Colpomenia peregrina & $\mathrm{Ps}$ & + & & & \\
\hline Dictyota furcellata & $\mathrm{P} \mathrm{cf}$ & + & & & \\
\hline Dictyota sp 2 & P cfo & + & & & \\
\hline Elachista sp 2 & Pf & + & & & \\
\hline Heterosiphonia sp 2 & $\mathrm{R} \mathrm{cf}$ & + & & & \\
\hline Heterosiphonia sp 1 & $\mathrm{R} \mathrm{cf}$ & + & & & \\
\hline Laurencia sp 2 & $\mathrm{R} \mathrm{cf}$ & + & & & \\
\hline Polysiphonia sp 1 & $\mathrm{R} \mathrm{cf}$ & + & & & \\
\hline Ulva sp 1 & $\mathrm{C}$ fo & + & & & \\
\hline Enteromorpha sp 1 & $C$ fo & + & + & & \\
\hline Polycerea zostericola & $\mathrm{Rf}$ & + & + & & \\
\hline Giffordia sp 1 & $\mathrm{Rf}$ & + & + & & + \\
\hline Encrusting coralline & $\mathrm{Re}$ & + & + & + & + \\
\hline Polycera nigrecens & $\mathrm{Pf}$ & + & + & + & + \\
\hline Ceramiium faccidium & $\mathrm{R} \mathrm{cf}$ & + & & + & \\
\hline Ceramium filicilum & $\mathrm{R} \mathrm{cf}$ & + & & + & \\
\hline Ceramium isogonum & $\mathrm{R} \mathrm{cf}$ & + & & + & \\
\hline Cladophora sp 1 & $\mathrm{Cf}$ & + & & + & \\
\hline Dasya sp 1 & $\mathrm{C}$ cf & + & & + & \\
\hline Derbesia tenuissima & $\mathrm{Cf}$ & + & & + & \\
\hline Hirsutithallia sp 1 & $\mathrm{R} \mathrm{cf}$ & + & & + & \\
\hline Polysiphonia forfex & $\mathrm{R} \mathrm{cf}$ & + & & + & \\
\hline Semnocarpa minuta & $\mathrm{Rs}$ & + & & + & \\
\hline Ceramium puberbulum & $\mathrm{R} \mathrm{cf}$ & + & & + & + \\
\hline Champia zostericola & $\mathrm{Rs}$ & + & & + & + \\
\hline \multicolumn{6}{|l|}{$\begin{array}{l}\text { Additional species found } \\
\text { only after } 8 \mathrm{wk}\end{array}$} \\
\hline Antithamnion sp 3 & $\mathrm{R} \mathrm{cf}$ & & & + & \\
\hline Asperococcus bullosus & $\mathrm{Rs}$ & & & + & \\
\hline Caulerpa distichohylla & $\mathrm{Cs}$ & & & + & \\
\hline Glossophora sp 1 & P cfo & & & + & \\
\hline Griffithsia australe & $\mathrm{Rf}$ & & & + & \\
\hline Нурпеа sp 1 & $\mathrm{R} \mathrm{cf}$ & & & + & \\
\hline Hypnea sp 2 & $\mathrm{R} \mathrm{cf}$ & & & + & \\
\hline Laurencia majuscula & $\mathrm{R} \mathrm{cf}$ & & & + & \\
\hline Mychodea pusilla & $\mathrm{R} \mathrm{cf}$ & & & + & \\
\hline Phaeophyta sp 3 & P cfo & & & + & \\
\hline Antithamnion sp 1 & $\mathrm{R} \mathrm{cf}$ & & & + & + \\
\hline Cladophora lehmanniana & $\mathrm{Cf}$ & & & & + \\
\hline Cladophora sp 3 & $\mathrm{Cf}$ & & & & + \\
\hline Dasya naccarioides & $\mathrm{C} \mathrm{cf}$ & & & & + \\
\hline Ectocarpus sp 1 & $P f$ & & & & + \\
\hline Ectocarpus sp 2 & $\mathrm{Pf}$ & & & & + \\
\hline Feldmannia irregularis & $\mathrm{Pf}$ & & & & + \\
\hline Giffordia sp 2 & $P f$ & & & & + \\
\hline Giffordia sp 3 & $\mathrm{Pf}$ & & & & + \\
\hline Giraudya sphacelarioides & $\mathrm{Pf}$ & & & & + \\
\hline Hincksia mitchelliae & $\mathrm{Rf}$ & & & & + \\
\hline Rhodophyta sp 5 & $\mathrm{Rf}$ & & & & + \\
\hline Sphacellaria rigidula & $\mathrm{Pf}$ & & & & + \\
\hline Total no. species & 53 & 30 & 5 & 24 & 18 \\
\hline Proportion red (\%) & 58 & 60 & 60 & 75 & 39 \\
\hline Proportion brown (\%) & 21 & 17 & 20 & 8 & 44 \\
\hline Proportion green (\%) & 21 & 23 & 20 & 17 & 17 \\
\hline Proportion filamentous & 43 & 37 & 60 & 21 & 72 \\
\hline
\end{tabular}


8 wk contained more brown algae species. There was a significant interactive effect of tethering and time on mean species richness (Fig. 2, Table 1); after $4 \mathrm{wk}$, the $\mathrm{T}$ units contained significantly more species than UT leaves (30 and 5 species, respectively; Tukey-Kramer $p$ $<0.01$ ), but by Week 8 this difference was no longer significant, with 24 and 18 species recorded on $\mathrm{T}$ and UT leaves, respectively. Of the 18 species on UT leaves, the majority were not found on the $\mathrm{T}$ units and were overwhelmingly filamentous species.

While species richness was comparable after $8 \mathrm{wk}$, the assemblages on UT leaves contained 13 species that were not present on $\mathrm{T}$ leaves and were overwhelmingly dominated by filamentous algae $(72 \%$ of species), while the $\mathrm{T}$ leaves contained a more functionally diverse assemblage with filamentous $(21 \%)$, corticated filamentous (54\%) and 4 other functional groups $(25 \%)$ of algae. Ordination produced a clear separation of samples taken from $\mathrm{T}$ and UT ASUs (Fig. 3). After 4 wk, the epiphyte composition on UT leaves formed a discrete and tight cluster that was well separated from the less tightly clustered $\mathrm{T}$ leaves. By Week 8, the 2 sets of samples were closer to each other, though still clearly separated. Results from ANOSIM confirmed the significance of differences in epiphyte composition on T and UT units ( $\mathrm{R}=$ 0.593, $\mathrm{p}<0.01$; Table 3$)$ and between times $(\mathrm{R}=$ $0.709, \mathrm{p}<0.01$ ). The differences among $\mathrm{T}$ and UT units were greater at Week 4 than Week $8(R=0.910$ and 0.508 , respectively).

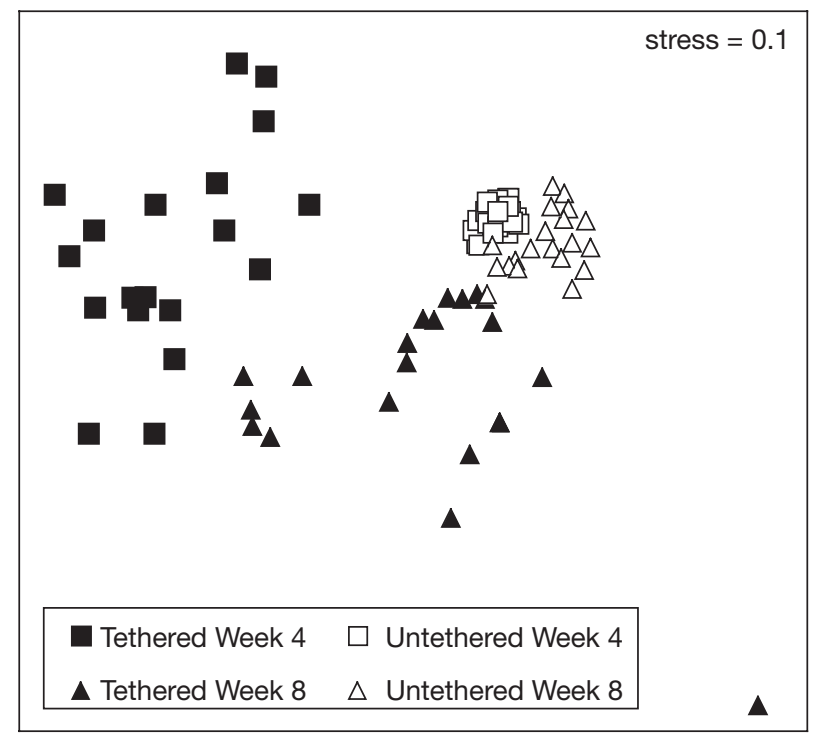

Fig. 3. Two-dimensional ordination (nonmetric multidimensional scaling) plot of epiphytic macroalgae samples on tethered and untethered artificial seagrass leaves at 4 and 8 wk after deployment. Ordination was based on Bray-Curtis similarity matrices constructed from untransformed percentage cover data
Table 3. Results of 2-factor crossed ANOSIM and pair-wise comparisons of macroalgal epiphyte assemblages on tethered (T) and untethered (UT) artificial seagrass units after $4 \mathrm{wk}(4)$ and 8 wk (8). Comparisons were made using Bray-Curtis similarity matrices based on untransformed \% cover data. In all cases, the number of permutations was 5000, and the significance (\%) was 0.0

\begin{tabular}{|lc|}
\hline Groups & R \\
\hline 4T, 4UT & 0.910 \\
$4 \mathrm{~T}, 8 \mathrm{~T}$ & 0.624 \\
4T, 8UT & 0.981 \\
4UT, 8T & 0.563 \\
4 UT, 8UT & 0.561 \\
8T, 8UT & 0.508 \\
\hline
\end{tabular}

\section{Influence of exposure}

Mean horizontal velocity at the exposed sites was $115 \mathrm{~cm} \mathrm{~s}^{-1}$ with a range of 15 to $165 \mathrm{~cm} \mathrm{~s}^{-1}$. At the sheltered sites, mean horizontal velocity was $25 \mathrm{~cm} \mathrm{~s}^{-1}$ with a range of 5 to $52 \mathrm{~cm} \mathrm{~s}^{-1}$. These measurements show a clear difference in water motion at the sites. The mean exposure index calculated for sheltered sites was 0.37 \pm 0.01 . For exposed sites, the majority of compass bearings yielded distances to land in excess of 1000s of km, so $L_{\mathrm{f}}$ was well in excess of 100 . Over the range used here, the degree of exposure (site) did not influence the effect of leaf movement on epiphyte biomass accumulation (Fig. 4, Table 1). However, DW and AFDW differed significantly between $\mathrm{T}$ and UT units. The mean biomass (DW) \pm SE on T ASUs at the sheltered sites was $0.59 \pm 0.06 \mathrm{~g} \mathrm{leaf}^{-1}$ and at the exposed site

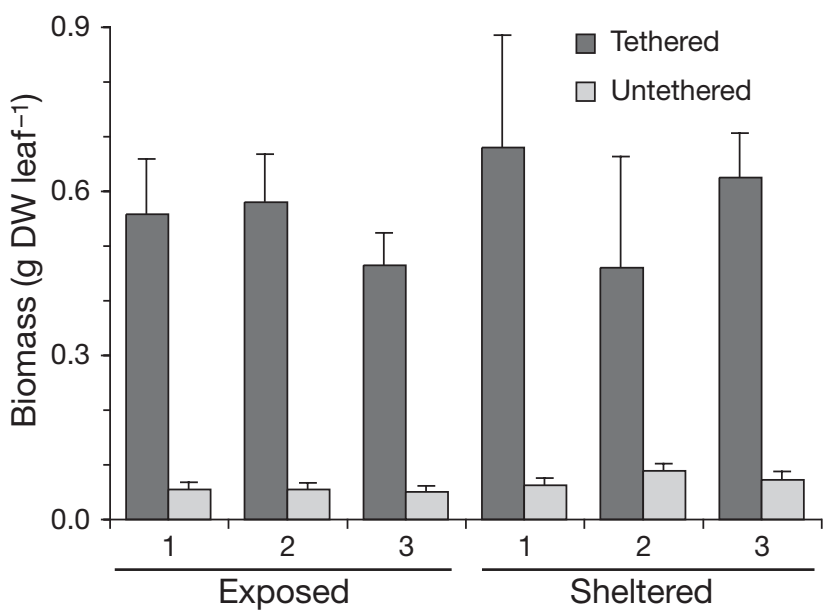

Fig. 4. Biomass (dry weight \pm SE) of epiphytic algae accumulated on tethered and untethered artificial seagrass leaves over 8 wk at 3 sheltered (off Garden Island) and 3 exposed (Marmion Marine Park) sites in SW Australia; $\mathrm{n}=5$. Ash free dry weight data not shown, as the trends were the same (see Table 1) 
was $0.46 \pm 0.10 \mathrm{~g} \mathrm{leaf}^{-1}$, compared to $0.07 \pm 0.01 \mathrm{~g}$ leaf $^{-1}$ and $0.05 \pm 0.01 \mathrm{~g} \mathrm{leaf}^{-1}$ on the UT units at the respective sites.

\section{Effect of depth}

The effect of tethering on epiphyte biomass was apparent at both depths, although the effect was greater at shallow sites (Fig. 5, Table 1), as shown by the significant depth $\times$ treatment interaction. At shallow sites, the mean DW of epiphytes on $\mathrm{T}$ units ranged from 0.26 to $0.92 \mathrm{~g} \mathrm{leaf}^{-1}$ compared to 0.06 to $0.10 \mathrm{~g}$ leaf $^{-1}$ for UT units. Similarly, T units placed at the deep sites had a higher algal biomass (0.12-0.14 $\mathrm{g} \mathrm{leaf}^{-1}$ ) than UT units $\left(0.04-0.06 \mathrm{~g} \mathrm{leaf}^{-1}\right)$. Thus, on $\mathrm{T}$ leaves, the mean algal biomass was 5 times higher in shallow sites compared to deep sites, while on UT units there was no difference.

\section{DISCUSSION}

Our results clearly show that leaf movement exerts a very strong control over the accumulation of epiphytes, possibly reducing the standing crop by an order of magnitude. Since the characteristics of epiphyte assemblages on this substrate and real seagrass leaves are similar (Horner 1987), we conclude that the effects noted here on ASUs can be considered analogous to those on seagrass leaves. Furthermore, the timescale of our experiment (up to $8 \mathrm{wk}$ ) is ecologically relevant, being within the turnover time of Posidonia leaves (Marbà \& Walker 1999, Collier 2006).

The effect of leaf movement has significant implications for seagrass production. Burt et al. (1995) empirically derived a relationship between epiphyte biomass on Posidonia leaves and the percentage reduction in

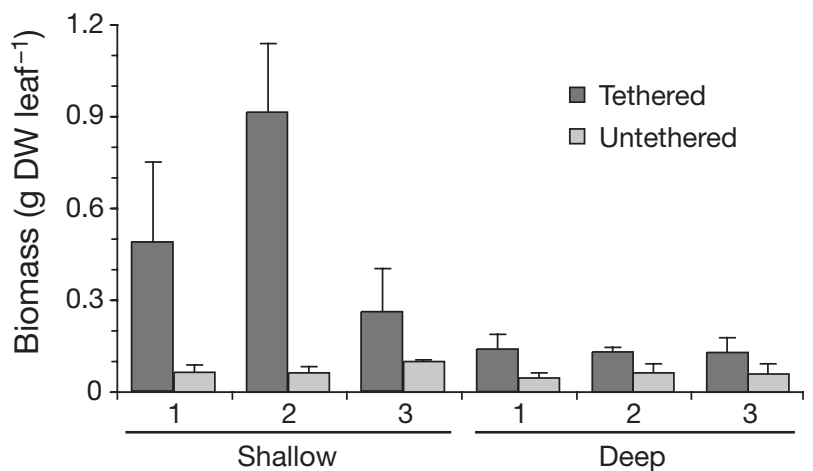

Fig. 5. Biomass (dry weight \pm SE) of epiphytic algae accumulated on tethered and untethered artificial seagrass leaves over 8 wk at 3 shallow and 3 deep sites off Garden Island, Western Australia; $\mathrm{n}=5$. Ash free dry weight data not shown, as the trends were the same (see Table 1) light penetration to the leaf surface $(y=17.651 \ln (x)+$ 44.556). On the basis of this relationship, the epiphyte biomass observed on T ASUs after 4 wk (Expt 1) could reduce photosynthetically active radiation (PAR) penetration to the leaf surface by as much as $32 \%$, while that on UT leaves would be over 5-fold lower (about $6 \%$ ). After $8 \mathrm{wk}$, there would be a 7 -fold difference in the reduction of PAR reaching the leaf due to accumulation of epiphyte biomass, with 51 and $7 \%$ reduction on $\mathrm{T}$ and UT leaves, respectively. This clearly demonstrates the potential benefits to the seagrass plant of reduced epiphyte cover through leaf movement, especially at depth or in turbid waters where production may be light limited.

The growth of epiphytes on leaves is strongly implicated in the loss of seagrasses at sites throughout the world and is generally viewed as a response to nutrient enrichment (Cambridge et al. 1986, Wear et al. 1999, Moore \& Wetzel 2000). Our results suggest that the effects of nutrient enrichment on epiphyte accumulation are ameliorated to some extent by leaf movement, and that the effects of nutrient enrichment would be most extreme at protected sites with low leaf movement. The differences we observed in this study were apparent over 4 to $8 \mathrm{wk}$, about half the longevity of Posidonia leaves (Cambridge \& Hocking 1997, Marbà \& Walker 1999), and it is possible that on natural leaves, the differences in epiphyte accumulations in highly protected and exposed sites would be greater. However, it appears that the relationship between leaf movement and epiphyte biomass is not linear. The effect of leaf movement was comparable at both the sheltered and exposed sites. Given the enormous differences in the degree of exposure, this suggests that even in relatively protected areas, leaf movement is sufficient to induce responses comparable to very exposed sites and indicates that the degree of movement at both sites was above the threshold required to affect epiphyte accumulation. On the other hand, Expt 3 showed that at depth, the effect of leaf movement was reduced, and we suggest that this is due to reduced water movement. Overall, this would indicate that the condition of no leaf movement is unlikely to occur, and that the threshold at which leaf movement affects epiphyte biomass is probably quite low, but that in some circumstances (e.g. highly sheltered and deep lagoon environments) movement may be reduced sufficiently for its control on epiphyte accumulation to be released or reduced.

In contrast to exposure, depth did influence the magnitude of effect that leaf movement had on epiphyte accumulation, with differences due to tethering being much less in deeper $(8 \mathrm{~m})$ locations. The average light attenuation coefficient $\left(k, \mathrm{~m}^{-1}\right)$ for these waters is 0.12 to $0.23 \mathrm{~m}^{-1}$, and the daily averaged photosynthetic 
photon flux density at $8 \mathrm{~m}$ is of the order of 1 to $4 \mathrm{~mol}$ $\mathrm{m}^{-2} \mathrm{~d}^{-1}$ (Collier 2006). Allowing for seasonal variation in day length, this equates to 20 to $100 \mu \mathrm{mol} \mathrm{m} \mathrm{m}^{-2} \mathrm{~d}^{-1}$. Factoring in additional light attenuation due to the seagrass canopy, which can be as much as $95 \%$ within $200 \mathrm{~mm}$ (Masini et al. 1995), light is likely to be limiting for many species of algae at this depth. In the absence of leaf movement, this difference in light availability probably accounts for the lower biomass on $\mathrm{T}$ units placed in $8 \mathrm{~m}$ of water, and was not unexpected. However, the lack of significant difference in biomass on UT leaves placed at the 2 depths was surprising. This indicates that when leaves are free to move, differences in light availability do not exert as strong an influence on the accumulation of epiphytes as does leaf movement. Given the overwhelming assumption that light and nutrients are the primary bottom-up controls of algal growth, this result is surprising and reinforces the need to take leaf movement into account when estimating epiphyte growth. Again, the extent of variation in leaf movement among natural seagrass sites remains unclear and warrants further investigation.

Our study did not set out to determine the mechanism by which leaf movement affects epiphyte standing crop. Conceptually, however, there are several mechanisms through which leaf movement could affect algal standing crop (Table 4), including mechanical erosion, availability of resources to epiphytes, reduced grazing pressure, altered recruitment of propagules or a combination of these. Leaf movement could cause the direct abrasion of epiphytes through contact with adjacent leaves, epiphytes or sediments.

Table 4. Summary of potential mechanisms of effect of leaf movement on epiphytic algal standing crop of seagrass leaves, and the nature of any effect $(+,-=$ increased, decreased algal biomass or productivity, respectively). Supporting literature is provided in the text

\begin{tabular}{|lcc|}
\hline $\begin{array}{l}\text { Proposed } \\
\text { mechanism }\end{array}$ & $\begin{array}{c}\text { Effect on } \\
\text { epiphytes }\end{array}$ & $\begin{array}{c}\text { Experimental } \\
\text { support }\end{array}$ \\
\hline $\begin{array}{l}\text { Flapping reduces boundary layer: } \\
\text { higher solute exchange }\end{array}$ & + & no \\
$\begin{array}{l}\text { Flapping reduces boundary layer: } \\
\text { higher local drag force }\end{array}$ & - & yes \\
$\begin{array}{l}\text { Flapping reduces boundary layer: } \\
\text { higher contact rate with spores }\end{array}$ & + & no \\
$\begin{array}{l}\text { Oscillation exerts a momentum force: } \\
\text { high peak force due to epiphyte momentum }\end{array}$ & - & yes \\
$\begin{array}{l}\text { Free leaf movement causes leaf interactions: } \\
\text { abrasion of epiphytes }\end{array}$ & - & yes \\
$\begin{array}{l}\text { Flapping causes substrate bending: } \\
\text { adhesive failure of epiphytes }\end{array}$ & - & yes \\
$\begin{array}{l}\text { Free leaf movement causes reduction in } \\
\text { grazer density: less herbivory on epiphytes }\end{array}$ & + & no \\
$\begin{array}{l}\text { Free leaf movement produces more horizontal } \\
\text { leaf canopy: increased canopy light attenuation }\end{array}$ & - & yes \\
\hline
\end{tabular}

In the Baltic Sea, the movement of Fucus vesiculosus fronds scours filamentous algal assemblages from the surrounding hard substrate (the 'whiplash effect'; Kiirikki 1996). In that study, it was assumed that if the later successional species (Fucus) was physically more resistant to abrasion than its epiphytes (as per Littler \& Littler's [1980] functional-form model), then the whiplash effect could limit algal epiphyte accumulation. In our study, movement of seagrass leaves would exert a negative control on epiphyte standing stock, and the difference between the T and UT ASUs represents algal, and possibly carbonate, inputs to the surrounding seagrass meadow and the detritus pool available for transport to adjacent habitats.

Carruthers \& Walker (1997) found that average light attenuation by the canopy of the seagrass Amphibolis griffithii was higher in winter than summer and related this to higher leaf movement in winter; the repeated bending of the leaves in winter produced a more horizontal canopy structure with greater light attenuation. Given this, leaf movement in the experiments reported here might be expected to have contributed to lower epiphyte standing crop by reducing light availability.

Leaf movement may reduce propagule settlement onto seagrass leaves. Leaf movement is associated with increased water velocities at the leaf surface (Koch et al. 2006), and spore settlement is strongly reduced under moderate flow conditions (Vadas et al. 1990, Granhag et al. in press). In our study, after 4 wk, species richness of epiphytic algae was greater on $\mathrm{T}$ leaves, but this difference was short-lived. This indicates that leaf movement may influence the initial rate of recruitment but, over time, effects are minimal on species richness. It is also possible that the initial establishment of calcareous encrusting algae is due to their high mechanical resistance (Littler \& Littler 1980) and that once established, they facilitate the recruitment of less robust corticated and filamentous algae. The increase in the AFDW:DW ratio on UT leaves after 4 wk supports this, reflecting the early dominance by calcareous, encrusting algae followed by a gradual infilling of cover by small fleshy epiphytes (or competitive displacement of calcareous forms). The encrusting layer may facilitate spore settlement by increasing surface roughness in the viscous sublayer, just above the leaf surface. Settlement of algal spores in the viscous sub-layer is affected by water velocity (Okuda \& Neushul 1981), and it has been proposed that under oscilla- 
tory motion the layer can be substantially thinner, due to the steeper velocity gradients (Granhag et al. in press). Even very small increases in surface roughness, such as those that encrusting algae may create, can produce microenvironments with reduced water velocity in the viscous sub-layer for settlement (Callow et al. 2002). It is plausible, therefore, that the initial encrusting algal layer acts as a facilitator (sensu Connell \& Slatyer 1977) in the succession of epiphytes and is a necessary precursor for the development of the epiphyte assemblage in oscillating conditions.

Filamentous algae dominated the assemblage that subsequently developed on the UT leaves. It is not clear why these forms dominated, but it is possibly related to the reduced mechanical drag experienced by thin filaments compared to thicker corticated forms; the drag experienced by a cylindrical object under simulated wave conditions increases dramatically with the size of the cylinder (see Denny 1994). However, epiphytic algal assemblages on natural seagrasses are frequently dominated by corticated filaments (Lavery \& Vanderklift 2002), suggesting that any initial selection for filamentous forms must not persist.

Some effects of leaf movement can conceivably favour epiphyte productivity (Table 4); oscillating leaf movement can enhance water exchange, and therefore nutrient availability, through canopies (Ghisalberti \& Nepf 2002, Koch et al. 2006), and the associated increases in water velocity are known to enhance nutrient uptake rates by epiphytic algae (Cornelisen \& Thomas 2002). Similarly, leaf movement can affect grazer biomass with positive effects on epiphyte biomass. Schanz et al. (2002) demonstrated that unidirectional (tidal) water movement caused the removal of grazers from seagrass leaves, releasing algal epiphytes from top-down control and resulting in an increased epiphyte biomass under high flow condition. In our study, epiphyte biomass was clearly lower under higher movement conditions, suggesting that any positive effects of leaf movement associated with increased resource availability or reduced herbivory were offset by the negative effects of leaf movement.

In summary, leaf movement can reduce the standing crop of epiphytic algae on ASUs 6- to 12-fold, and is likely to have a similar effect on natural seagrass leaves. A variety of processes could be contributing to this effect, the relative contributions of which are unclear at this stage. Irrespective of the precise mechanisms involved, the reduction in epiphyte biomass associated with leaf movement has potentially profound ecological significance, including the dramatic reduction of light attenuation caused by epiphytes on seagrass leaves. If the difference we have observed is due to loss of epiphytes rather than reduced production, then the level of erosion needs to be consid- ered when modelling the turnover rates of nutrients or production of carbonate by epiphytes in seagrass systems. Importantly, our results suggest the potential for leaf movement to exert control over algal standing crop and to strongly moderate any effect of light availability.

Acknowledgements. We thank R. Masini for the insightful discussions that led to this work, K. Moore for useful comments on a presentation of our study and J. How for assistance in the field. We also thank 3 anonymous reviewers for their insightful, constructive comments on the manuscript.

\section{LITERATURE CITED}

Borowitzka MA, Lavery PS, van Keulen M (2006) Epiphytes of seagrasses. In: Larkum AWD, Orth RJ, Duarte CM (eds) Seagrasses: biology, ecology and conservation. SpringerVerlag, Berlin, p 441-461

Burt JS, Kendrick GA, Masini RJ, Simpson CJ (1995) Light and Posidonia sinuosa seagrass meadows in the temperate coastal waters of Western Australia. II. Effect of epiphyte species assemblages and biomass on attenuating light to the leaf surface. Technical Series 61, Department of Environmental Protection, Perth

Callow ME, Jennings AR, Brennan AB, Seegert CE, Gibson A, Feinberg A, Baney R, Callow JA (2002) Microtopographic cues for settlement of zoospores of the green fouling alga Enteromorpha. Biofouling 18:237-245

Cambridge ML, Hocking PJ (1997) Annual primary production and nutrient dynamics of the seagrasses Posidonia sinuosa and Posidonia australis in south-western Australia. Aquat Bot 59:277-295

Cambridge ML, Chiffings AW, Brittan C, Moore L, McComb AJ (1986) The loss of seagrass in Cockburn Sound, Western Australia. II. Possible causes of seagrass decline. Aquat Bot 24:269-285

Carr MR (1997) PRIMER User Manual. Plymouth Routines in Multivariate Ecological Research, Plymouth Marine Laboratory, Plymouth

Carruthers TJB, Walker DI (1997) Light climate and energy flow in the seagrass canopy of Amphibolis grifithii (J.M. Black) den Hartog. Oecologia 109:335-341

Charters AC, Neushul M, Coon D (1973) The effect of water motion on algal spore adhesion. Limnol Oceanogr 18: 884-896

Collier CJ (2006) Characterisation of the seagrass Posidonia sinuosa's responses to light availability. PhD thesis, Edith Cowan University, Perth

Connell JH, Slatyer RO (1977) Mechanisms of succession in natural communities and their role in community stability and organization. Am Nat 111:119-144

Cornelisen CD, Thomas FIM (2002) Ammonium uptake by seagrass epiphytes: isolation of the effects of water velocity using an isotope label. Limnol Oceanogr 47: 1223-1229

Denny MW (1994) Extreme drag forces and the survival of wind and water-swept organisms. J Exp Biol 194:97-115

Frankovich TA, Zieman JC (1994) Total epiphyte and epiphytic carbonate production on Thalassia testudinum across Florida Bay. Bull Mar Sci 54:679-695

Ghisalberti M, Nepf HM (2002) Mixing layers and coherent structures in vegetated aquatic flows. J Geophys Res 107(C2):3011 
Granhag, LM, Larsson AI, Jonsson PR (2007) Algal spore settlement and germling removal as a function of flow speed. Mar Ecol Prog Ser (in press)

Håkansson L (1981) A manual of lake morphometry. Springer-Verlag, Berlin

Heck KL, Pennock JR, Valentine JF, Coen LD, Sklenar SA (2000) Effects of nutrient enrichment and small predator density on seagrass ecosystems: an experimental assessment. Limnol Oceanogr 45:1041-1057

Hegge BJ, Kendrick GA, Lavery PS, Campey ML, Nielson J, Lord DA (1998) The role of in-situ calcium carbonate production in the creation of a shallow subtidal sandbank, Success Bank, Western Australia. Unpublished Report, Cockburn Cement Ltd, Perth, Western Australia

Horner SMJ (1987) Similarity of epiphyte biomass distribution on Posidonia and artificial seagrass leaves. Aquat Bot 27: 159-167

Huisman, JM, Walker DI (1990) A catologue of the marine plants from Rottnest Island, Western Australia, with notes on their distribution and biogeography. Kingia 1:349-459

Iizumi H, Yamamuro M (2000) Nitrogen fixation by periphytic blue-green algae in a seagrass bed on the Great Barrier Reef. Jpn Agric Res Q 34:69-73

Jernakoff P, Brearley A, Nielsen J (1996) Factors affecting grazer-epiphyte interactions in temperate seagrass meadows. Oceanog Mar Biol Annu Rev 34:109-162

Kendrick GA, Lavery PS (2001) Assessing biomass, assemblage structure and production of algal epiphytes on seagrasses. In: Short FT, Coles RG (eds) Global seagrass research methods. Elsevier, Amsterdam, p 199-222

Kiirikki M (1996) Experimental evidence that Fucus vesiculosus (Phaeophyta) controls filamentous algae by means of the whiplash effect. Eur J Phycol 31:61-66

Klumpp DW, Salita-Espinosa JS, Fortes MD (1992) The role of epiphytic periphyton and macroinvertebrate grazers in the trophic flux of a tropical seagrass community. Aquat Bot 43:327-349

Koch EW, Ackerman JD, Verduin J, van Keulen M (2006) Fluid dynamics in seagrass ecology - from molecules to ecosystems. In: Larkum AWD, Orth RJ, Duarte CM (eds) Seagrasses: biology, ecology and conservation. Springer, Berlin, p 193-225

Lavery PS, Vanderklift MA (2002) A comparison of spatial and temporal patterns in epiphytic algal assemblages of the seagrasses Amphibolis griffithii and Posidonia coriacea. Mar Ecol Prog Ser 236:99-112

Lethbridge RC, Borowitzka MA, Benjamin K (1988) The development of an artificial Amphibolis-like seagrass of complex morphology and preliminary data on its colonisation by epiphytes. Aquat Bot 31:153-168

Littler MM, Littler DS (1980) The evolution of thallus form and survival strategies in benthic marine macroalgae: field and laboratory tests of a functional model. Am Nat 116: $25-44$

Marbà N, Walker DI (1999) Growth, flowering and population dynamics of temperate Western Australian seagrasses. Mar Ecol Prog Ser 184:105-118

Masini RJ, Burt JS, Simpson CJ (1995) Light and Posidonia seagrass meadows in the temperate coastal waters of Western Australia. III. Minimum light requirements. Technical Series 65, Department of Environmental Protection, Perth

Moore KA, Wetzel RL (2000) Seasonal variations in eelgrass (Zostera marina L.) responses to nutrient enrichment and

Editorial responsibility: Howard Browman (Associate Editorin-Chief), Storebø, Norway reduced light availability in experimental ecosystems. J Exp Mar Biol Ecol 244:1-28

Nikora VI, Goring DG (1998) ADV measurements of turbulence: Can we improve their interpretation? J Hydraul Eng 124:630-634

Okuda T, Neushul M (1981) Sedimentation studies of red algal spores. J Phycol 17:113-118

OUP (Open University Press Team) (1989) Waves, tides and shallow water processes. Pergamon Press, Oxford

Patriquin D (1972) Carbonate mud production by epibionts on Thalassia: an estimate based on leaf growth data. J Sediment Petrol 42:687-689

Pattiaratchi C, Hegge B, Gould J, Eliot I (1997) Impact of seabreeze activity on nearshore and foreshore processes in southwestern Australia. Cont Shelf Res 17:1539-1560

Pereg-Gerk L, Sar N, Lipkin Y (2002) In situ nitrogen fixation associated with seagrasses in the Gulf of Elat (Red Sea). Aquat Ecol 36:387-394

Pinckney JL, Micheli F (1998) Microalgae on seagrass mimics: Does epiphyte community structure differ from live seagrasses? J Exp Mar Biol Ecol 221:59-70

Schanz A, Polte P, Asmus H (2002) Cascading effects of hydrodynamics on an epiphyte-grazer system in intertidal seagrass beds of the Wadden Sea. Mar Biol 141: 287-297

Silberstein K, Chiffings AW, McComb AJ (1986) The loss of seagrass in Cockburn Sound, Western Australia. III. The effect of epiphytes on productivity of Posidonia australis Hook F. Aquat Bot 24:355-371

Vadas RL, Wright WA, Miller SL (1990) Recruitment of Ascophyllum nodosum: wave action as a source of mortality. Mar Ecol Prog Ser 61:263-272

Verduin JJ (1996) In situ submarine pollination in Amphibolis antarctica (Labill.) Sonder et Aschers. ex Aschers. and its relation to hydrodynamics. In: Kuo J, Phillips RC, Walker DI, Kirkman H (eds) Seagrass biology: proceedings of an international workshop. University of Western Australia, Perth, p 123-128

Walker DI, McComb AJ (1992) Seagrass degradation in Australian coastal waters. Mar Pollut Bull 21:197-203

Walker DI, Woelkerling WJ (1988) Quantitative study of sediment contribution by epiphytic coralline red algae in seagrass meadows in Shark Bay, Western Australia. Mar Ecol Prog Ser 43:71-77

Wear DJ, Sullivan MJ, Moore AD, Millie DF (1999) Effects of water-column enrichment on the production dynamics of three seagrass species and their epiphytic algae. Mar Ecol Prog Ser 179:201-213

Wikström SA, von Wachenfeldt T, Kautsky L (2002) Establishment of the exotic species Fucus evanescens C. Ag. (Phaeophyceae) in Öresund, Southern Sweden. Bot Mar 45:510-517

Womersley HBS (1984) The marine benthic flora of southern Australia. Part I. South Australian Government Printing Division, Adelaide

Womersley HBS (1987) The marine benthic flora of southern Australia. Part II. South Australian Government Printing Division, Adelaide

Womersley HBS (1994) The marine benthic flora of southern Australia. Part IIIA. South Australian Government Printing Division, Adelaide

Womersley HBS (1996) The marine benthic flora of southern Australia. Part IIIB. South Australian Government Printing Division, Adelaide 